Perception and Prejudice 
This page intentionally left blank 


\section{Perception and Prejudice}

Race and Politics in the United States

Edited by Jon Hurwitz and Mark Peffley

Yale University Press

New Haven and London 
Copyright (C) 1998 by Yale University.

All rights reserved.

This book may not be reproduced, in whole or in part, including illustrations, in any form (beyond that copying permitted by Sections 107 and 108 of the U.S. Copyright Law and except by reviewers for the public press), without written permission from the publishers.

Set in Adobe Garamond type by The Composing Room of Michigan, Inc., Grand Rapids, Michigan

Printed in the United States of America

Library of Congress Cataloging-in-Publication Data

Perception and prejudice : race and politics in the United States edited by Jon Hurwitz and Mark Peffley.

p. $\mathrm{cm}$.

Includes bibliographical references and index.

ISBN 0-300-07143-4 (cloth : alk.paper)

I. United States-Race relations. 2. Racism-Political aspects-United States. 3. United States-Politics and government-I993-Attitudes.

I. Hurwitz, Jon. II. Peffley, Mark. 4. United States-

1993 5. Whites_-United States-

EI85.615.P415 1998

$305.8^{\prime} 00973-\mathrm{dc2I}$

$97-44948$

CIP

A catalogue record for this book is available from the British Library.

The paper in this book meets the guidelines for permanence and durability of the Committee on Production Guidelines for Book Longevity of the Council on Library Resources.

I0 $\quad \begin{array}{lllllllll}9 & 8 & 7 & 6 & 5 & 4 & 3 & 2 & \text { I }\end{array}$ 